Journal of Animal and Veterinary Advances 11 (18): 3399-3404, 2012

ISSN: $1680-5593$

(C) Medwell Journals, 2012

\title{
Effects of Dietary Silymarin Supplementation on Growth Performance and Oxidative Status in Carassius auratus gibelio
}

\author{
${ }^{1}$ Dan Yi, ${ }^{1}$ Lingfang Gu, ${ }^{1}$ Binying Ding, ${ }^{1}$ Ming Li, ${ }^{1}$ Yongqing Hou, \\ ${ }^{1}$ Lei Wang and ${ }^{2}$ Joshua Gong \\ ${ }^{1}$ Hubei Key Laboratory of Animal Nutrition and Feed Science, \\ Wuhan Polytechnic University, 430023 Wuhan, China \\ ${ }^{2}$ Guelph Food Research Centre, Agriculture and Agri-Food Canada, Guelph, \\ Ontario, N1G 5C9 Canada
}

\begin{abstract}
This study was conducted to investigate the effects of dietary silymarin supplementation on growth performance and oxidative status in Carassius auratus gibelio. About 270 fishes (C. auratus gibelio) were randomly assigned to the following groups: the control group was fed a basal diet; flavomycin group and silymarin group were fed a basal diet supplemented with $4 \mathrm{mg} \mathrm{kg}^{-1}$ flavomycin and $100 \mathrm{mg} \mathrm{kg}^{-1}$ silymarin, respectively. After 8 weeks feeding, body weight and feed intake were recorded. Blood, liver and muscle sample were also collected for determining the biochemical parameters, oxidative status, protein, RNA and DNA levels. No significant differences in growth performance and body composition of fishes were observed among three groups. However, dietary supplementation with silymarin increased the levels of blood total protein and globulin as compared to flavomycin group. Fishes receiving silymarin exhibited a lower level of malondialdehyde in serum and liver compared to control and flavomycin groups whereas levels of liver and serum superoxide dismutase were not affected. In addition, dietary silymarin increased the ratio of protein to RNA of liver whereas did not affect the ratio of RNA to DNA in muscle and liver. Collectively, these data suggested that dietary supplementation of $100 \mathrm{mg} \mathrm{kg}^{-1}$ silymarin increased the protein synthesis and potentially improved the antioxidative capacity in C. auratus gibelio.
\end{abstract}

Key words: Silymarin, body composition, growth performance, antioxidant, Carassius auratus gibelio, liver

\section{INTRODUCTION}

The ban of antibiotic growth promoters of Europe and the expected spread of the rest of the world have driven the implementation of alternative strategy in aquaculture industry. Herbal compounds such as phenolics, polyphenols, alkaloids, quinines, terpenoids, lectines and polypeptides have been shown to be very effective replacement to antibiotics and other compounds without residue and side effects (Citarasu, 2010). These natural plant extracts have been reported to increase the ability of antistress, promote growth and enhance the immune response in pigs (Kong et al., 2007; Yin et al., 2008a, b); shrimp and finfish (Citarasu et al., 1999; Sivaram et al., 2004). Therefore, researches about the efficacy of herbal compounds in aquaculture animals are necessary and valuable.

Silymarin is a flavonolignans that has been introduced as a hepatoprotective agent. It was extracted from seeds of Silybum marianum (Family: Composite) and composed of four isomeric flavonolignans: silibinin (active component), isosilibinin, silydianin and silychristin (Saller et al., 2001). Silymarin have been used widely for production against disease of the liver and the biliary tract (Pradeep et al., 2007) as well as menstrual disorders and varicose veins (Saller et al., 2001). It is also shown to be an effective antidote for protection against environmental toxin such as $\mathrm{CCl}_{4}$ (Muriel and Murelle, 1990), acetaminophen (Muriel et al., 1992), palloidin, galactosamine and thioacetamide (Fraschini et al., 2002). These beneficial effects of silymarin were correlated to its antioxidant (Kiruthiga et al., 2007), anti-inflammatory (Kang et al., 2004) anticarcinogenic and antifibrotic properties as well as membrane stabilization and GSH modulation (Fraschini et al., 2002). In aquaculture, Banaee et al. (2011) have studied the effect of silymarin on blood biochemical parameters of rainbow trout showing that silymarin reduced plasma glucose and cholesterol levels and relatively increased plasma total protein and globulin concentrations. Up to date,

Corresponding Author: Yongqing Hou, Hubei Key Laboratory of Animal Nutrition and Feed Science, Wuhan Polytechnic University, Changqing Garden, Wuhan, 430023 Hubei, P.R. China 
knowledge is limited about efficacy of silymarin in aquaculture fishes. The current study is conducted to investigate the effects of dietary silymarin supplementation on growth performance and oxidative status in Carassius auratus gibelio.

\section{MATERIALS AND METHODS}

Diets and grouping: The 270 fishes (Carassius auratus gibelio Autumn fingerlings) were randomly assigned to three dietary treatment groups (control, flavomycin and silymarin group). The Control group (C) was fed a basal diet; Flavomycin group (F) and Silymarin group (S) were fed a basal diet supplemented with $4 \mathrm{mg} \mathrm{kg}^{-1}$ flavomycin and $100 \mathrm{mg} \mathrm{kg}^{-1}$ silymarin, respectively. Flavomycin (Eli Lilly and Company, Shanghai, China) was employed in this study as an positive control to test the efficiency of silymarin on growth performance of fishes. The silymarin (80\%; Hetian Biotech, Hangzhou, China) was dissolved in distilled water and then mixed thoroughly with the basal feed. This mixture was dried and broken to pellets which stored at $-20^{\circ} \mathrm{C}$ until be used (Banaee et al., 2011). The dosage of $100 \mathrm{mg} \mathrm{kg}^{-1}$ silymarin used in this study was chosen according to its antioxidant properties and the previous study. The antioxidant activity of silymarin was evaluated by the 2, 2-Diphenyl-1Picrylhydrazyl (DPPH) radical assay (Iwashima et al., 2005). The composition and nutrient content of the basal diet were shown in Table 1.

Fishes and feeding regime: The 270 fishes (Carassius auratus gibelio Autumn fingerlings) with an average body weight of $12.84 \pm 0.12 \mathrm{~g}$ were obtained from a local hatchery farm (Hubei, China) and were transferred to the aquaculture tanks $(100 \times 60 \times 60 \mathrm{~cm})$. The fishes were

Table 1: Composition and nutrient content of the basal diet

\begin{tabular}{lclc}
\hline Ingredients & Percentage $(\%)$ & Nutrient levels & Percentage $(\%)$ \\
\hline Soybean meal & 44.10 & Moisture & 9.30 \\
Wheat middling & 24.40 & Crude protein & 33.47 \\
Cottonseed meal & 10.00 & Crude ash & 8.90 \\
Rapeseed meal & 8.00 & Ether extract & 3.95 \\
Fish meal & 5.00 & Calcium & 0.81 \\
Soybean oil & 3.00 & Total Phosphorus & 0.62 \\
Bentonite & 2.00 & - & - \\
Monocalcium phosphate & 1.50 & - & - \\
Adhesive & 0.50 & - & - \\
Choline & 0.30 & - & - \\
Salt & 0.20 & - & - \\
Premix & 1.00 & - & - \\
\hline
\end{tabular}

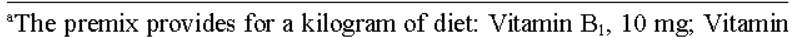
$\mathrm{B}_{2}, 20 \mathrm{mg}$; Vitamin $\mathrm{B}_{6}, 30 \mathrm{mg}$; Vitamin $\mathrm{B}_{12}, 0.020 \mathrm{mg}$; Folic acid, $5 \mathrm{mg}$; Calcium pantotheniate, $50 \mathrm{mg}$; Inositol, $100 \mathrm{mg}$; Niacin, $100 \mathrm{mg}$; Biotin, $0.5 \mathrm{mg}$; Vitamin C, $100 \mathrm{mg}$; Vitamin A, $8000 \mathrm{IU}$; Vitamin D, $2000 \mathrm{IU}$; Vitamin E, $100 \mathrm{mg}$; Vitamin $\mathrm{K}, 10 \mathrm{mg} ; \mathrm{Mg}, 250 \mathrm{mg} ; \mathrm{Fe}, 80 \mathrm{mg}$; Cu, $2 \mathrm{mg}$; Mn, $20 \mathrm{mg}$; Zn, $60 \mathrm{mg}$; I, $1.0 \mathrm{mg}$; Se, $0.3 \mathrm{mg}$; ${ }^{b}$ Calculated values acclimated to laboratory conditions for 2 weeks prior to experiment. Water condition and quality characteristics were measured daily: average temperature $26 \pm 6^{\circ} \mathrm{C} ; \mathrm{pH}$, $7.2 \pm 0.2$; Ammonia nitrogen, $<0.2 \mathrm{mg} \mathrm{L}^{-1}$; dissolved oxygen, $5.0 \pm 0.1 \mathrm{mg} \mathrm{L}^{-1}$. The fishes were maintained on a photoperiod with $12 \mathrm{~h}$ light $/ 12 \mathrm{~h}$ dark with the light period from 8:00 am to $20: 00$ pm by 3 lamps. During acclimation, fishes were fed with prepared pellet feed at an amount of $2 \%$ of their body weight twice feeding per day.

During the experiment, three treatment diets were randomly assigned to the Carassius auratus gibelio that were reared in triplicate tanks for 8 weeks. Each tank held 30 fishes. Fishes were fed to apparent satiation twice daily (9:00 am and 15:00 pm), the feeding trail lasted 8 weeks. At each feeding, an excess quantity of the diet was provided and uneaten diet was collected $1.5 \mathrm{~h}$ after feeding.

Sampling procedure and analysis: The individual body weights of fish were recorded at the start of the trial and at the end of experiment and feed intake was measured to evaluate the growth and feed efficiency. At the end of 8 weeks feeding trail, 9 fishes from each tank were sampled blood from from the caudal vein into sterilized vials at $4^{\circ} \mathrm{C}$. The blood was centrifuged at $3000 \times \mathrm{g}$ for $10 \mathrm{~min}$ at $4^{\circ} \mathrm{C}$ to obtain plasma (Yin et al., 2000). The 9 fishes from each tank were killed by a sharp blow to the head and dissected on an ice pan. Back muscle and liver were carefully removed under sterile conditions and washed in sterilized saline. Liver and muscle samples were immediately stored at $-80^{\circ} \mathrm{C}$ until analysis. All the rest of fishes in each tank were sampled for analysis of final body composition.

Blood biochemical parameters: Serum levels of Alkaline Phosphatase (AKP), Glutamic-Pyruvic Transaminase (GPT), Glutamic-Oxaloacetic Transaminase (GOT), Total Protein (TP), Albumin (ALB), Globulin (GLB) and Blood Urea Nitrogen (BUN) were determined with automatic biochemical analyzer (Model 7020, Hitachi, Japan) according to the instructions from manufacture's manual.

Antioxidant activity and lipid peroxidation: Liver samples was excised, washed in ice cold saline and blotted to dryness. A $1 \%$ homogenate of the liver was prepared in Tris- $\mathrm{HCl}$ buffer $\left(0.1 \mathrm{~mol} \mathrm{~L}^{-1} ; \mathrm{pH} 7.4\right)$, centrifuged at $1000 \mathrm{rpm}$ for $10 \mathrm{~min}$ at $4^{\circ} \mathrm{C}$, aliquots of supernatant were used for further analysis. Malondialdehyde (MDA) in liver and serum was determined by thiobarbituric acid reaction as described by Ohkawa et al. (1979) while the Superoxide Dismutase (SOD) activity was estimated by the method according to Sun et al. (1989) and Li et al. (2007). 
Liver and muscle DNA, RNA and protein: Frozen liver and muscle samples (about $0.1 \mathrm{~g}$ ) were powdered under liquid nitrogen using a mortar and pestle and then homogenized with a tissue homogenizer in $1 \mathrm{~mL}$ of ice-cold PBS-EDTA buffer $\left(0.05 \mathrm{~mol} \mathrm{~L} \mathrm{~L}^{-1} \quad \mathrm{Na}_{3} \mathrm{PO}_{4}\right.$, $2.0 \mathrm{~mol} \mathrm{~L}^{-1} \mathrm{NaCl}, 2 \mathrm{mmol} \mathrm{L}^{-1} \mathrm{EDTA}, \mathrm{pH} 7.4$ ) according to the method of Yao et al. (2008). Protein concentration of liver and muscle homogenates was measured as described by Lowry et al. (1951) using reagents from BioRad Laboratories (Hercules, CA, USA) and bovine serum albumin as the standard. The extraction of liver and muscle RNA was processed according to the method of Fleck and Munro (1962). In brief, frozen tissues were powered and homogenized in ice-cold saline solution $(85 \%)$. About $2 \mathrm{~mL}$ of a cold homogenates were transferred to a centrifuge tube and $1 \mathrm{~mL}$ ice-cold $0.6 \mathrm{~mol} \mathrm{~L}^{-1} \mathrm{HClO}_{4}$ added. After mixing the solution and keeping on ice $10 \mathrm{~min}$, centrifuged at $4^{\circ} \mathrm{C}$ and washed

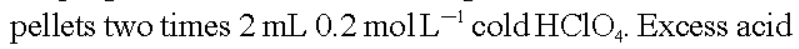
was removed and $2 \mathrm{~mL} 0.3 \mathrm{~mol} \mathrm{~L}^{-1} \mathrm{KOH}$ added and then incubated at $37^{\circ} \mathrm{C}$ for $1 \mathrm{~h}$. The alkaline solution was cooled on ice and $1 \mathrm{~mL}$ cold $1.2 \mathrm{~mol} \mathrm{~L}^{-1} \mathrm{HClO}_{4}$ added. After centrifuging the mixture, the supernatant (the acid-soluble RNA fraction) was adjusted to a suitable volume for spectrometry assay at the wavelength of 260 and $232 \mathrm{~nm}$ to determine the quantity of mucosal RNA (Fleck and Begg, 1965). On the other hand, the pellets were collected to extract and determine DNA (Ceriotti, 1955). Briefly, the pellets were dissolved in $4 \mathrm{~mL}$ cold $1 \mathrm{~mol} \mathrm{~L}^{-1} \mathrm{HClO}_{4}$ solution and boiled for $10 \mathrm{~min}$ and then cooled in ice. After centrifuging the mixture, the supernatant was adjusted to a suitable volume for spectrometry assay at the wavelength of 260,280 and $320 \mathrm{~nm}$ to determine the quantity of DNA.

Chemical analyses: The chemical composition of the freeze dried fish was analyzed according to standard methods: crude protein was measured by Macro Kjeldal Method, crude lipids by extraction with petroleum ether and ash by burning in a muffle furnace (Yin et al., 1993).

Statistical analysis: Results are expressed as means with $\mathrm{SD}$ and analyzed by one-way Analysis of Variance (ANOVA) using SPSS System (SPSS Inc. Chicago, IL, USA). Differences among treatment groups were determined by Duncan's multiple range test. The $\mathrm{p}<0.05$ were taken to indicate significance.

\section{RESULTS}

Growth, feed performance and body carcass composition: Data of growth performance and body carcass composition were shown in Table 2. At the end of the experiment, there were no significances in growth and feed performance among three treatment groups ( $p>0.05$ ). Similarly, the average protein, fat and ash contents of the carcass did not differ ( $>0.05)$ between experimental and control groups.

Blood biochemical parameters: The changes of blood biochemical parameters were shown in Table 3. Diet supplemented with flavomycin or silymarin did not affect the activities of blood GPT and GOT $(\mathrm{p}>0.05)$. Dietary silymarin increased $(\mathrm{p}<0.05)$ the levels of blood TP and GLB as compared to flavomycin groups while no differences were observed in these parameters in comparison with control group ( $\mathrm{p}>0.05)$. In addition, levels of blood ALB and BUN of experimental fishes were not affected by administration of flavomycin or silymarin.

Ratio of RNA/DNA and protein/RNA of liver and muscle: Compared with control and flavomycin groups, fishes receiving silymarin diet had a higher ratio of protein to

Table 2: Growth performance of Carassius curatus gibelio in different dietary treatments

\begin{tabular}{lrrr}
\hline Parameters & \multicolumn{1}{c}{$\mathrm{C}$} & $\mathrm{F}$ & $\mathrm{S}$ \\
\hline Growth and feed performance $(\mathbf{n}=\mathbf{1 5})$ & & & $12.86 \pm 0.07$ \\
Initial live mass (g) & $12.85 \pm 0.07$ & $21.67 \pm 0.95$ & $12.81 \pm 0.18$ \\
Final live mass (g) & $21.59 \pm 0.65$ & $68.46 \pm 6.96$ & $21.81 \pm 0.69$ \\
Weight gain ratio (WGR, \%) & $68.06 \pm 6.81$ & $2.79 \pm 0.19$ & $70.27 \pm 5.53$ \\
Feed conversion ratio (FCR, \%) & $2.82 \pm 0.10$ & $1.08 \pm 0.07$ & $2.75 \pm 0.11$ \\
Protein efficiency ratio (PER, \%) & $1.06 \pm 0.04$ & $0.41 \pm 0.03$ & $1.09 \pm 0.04$ \\
Specific growth rate (SGR, \% day ${ }^{-1}$ ) & $0.40 \pm 0.03$ & & $0.41 \pm 0.03$ \\
Body composition (n= 9) & & $68.64 \pm 2.75$ & $70.08 \pm 2.63$ \\
Crude protein (N×6.25) (\% of dry matter) & $67.69 \pm 3.88$ & $6.89 \pm 0.43$ & $7.07 \pm 0.37$ \\
Crude fat (\%) & $6.53 \pm 0.49$ & $8.62 \pm 0.49$ & $8.57 \pm 0.10$ \\
Ash (\%) & $8.50 \pm 0.27$ & \\
\hline
\end{tabular}

Values within a row with different letters differ $(\mathrm{p}<0.05)$. Data were represented as means with SD. C: fish fed with control diet; $\mathrm{F}$ : fish fed with $4 \mathrm{mg} \mathrm{kg}^{-1}$ flavomycin; S: Fish fed with $100 \mathrm{mg} \mathrm{kg}^{-1}$ silymarin; WGR = Live Weight Gain/Initial live weight; FCR = Feed Consumed/Live weight gain; PER = Wet weight gain/protein ingested; SGR $=[\ln$ (Final body weight)-ln (Initial body weight) $] /$ Experimental days 
Table 3: Blood biochemical parameters of Carassius auratus gibelioin different dietary treatments

\begin{tabular}{|c|c|c|c|}
\hline Parameters & $\mathrm{C}$ & $\mathrm{F}$ & $\mathrm{S}$ \\
\hline GPT $\left(\mathrm{UL}^{-1}\right)$ & $18.50 \pm 5.55$ & $16.54 \pm 4.89$ & $15.57 \pm 3.16$ \\
\hline GOT $\left(\mathrm{UL}^{-1}\right)$ & $326.6 \pm 94.79$ & $325.0 \pm 77.25$ & $301.36 \pm 56.2$ \\
\hline $\mathrm{TP}\left(\mathrm{gL}^{-1}\right)$ & $33.56 \pm 3.78^{\mathrm{ab}}$ & $32.35 \pm 2.51^{b}$ & $34.85 \pm 2.67^{a}$ \\
\hline $\operatorname{ALB}\left(\mathrm{g} \mathrm{L}^{-1}\right)$ & $20.30 \pm 5.29$ & $21.57 \pm 1.45$ & $21.88 \pm 2.12$ \\
\hline $\operatorname{GLB}\left(\mathrm{g} \mathrm{L}^{-1}\right)$ & $13.26 \pm 1.66^{\mathrm{a}}$ & $10.78 \pm 1.87^{b}$ & $12.97 \pm 1.36^{\mathrm{a}}$ \\
\hline BUN $\left(\mathrm{g} \mathrm{L}^{-1}\right)$ & $0.47 \pm 0.21$ & $0.42 \pm 0.15$ & $0.41 \pm 0.09$ \\
\hline
\end{tabular}

Values within a row with different letters differ $(p<0.05)$. Data were represented as means with $\mathrm{SD}$. $n=9$. C: Fish fed with control diet; F: Fish fed with $4 \mathrm{mg} \mathrm{kg}^{-1}$ flavomycin; S: Fish fed with $100 \mathrm{mg} \mathrm{kg}^{-1}$ silymarin

Table 4: Ratio of RNA/DNA and protein/DNA of liver and muscle of Carassius curctus gibelio in different dietary treatments

\begin{tabular}{lccc}
\hline Parameters & C & F & S \\
\hline Liver (n = 9) & & & \\
RNA/DNA (\%) & $2.74 \pm 0.52$ & $2.81 \pm 0.48$ & $2.58 \pm 0.31$ \\
Protein/RNA (\%) & $3.77 \pm 0.56^{b}$ & $3.76 \pm 0.34^{b}$ & $4.57 \pm 0.56^{\mathrm{a}}$ \\
Muscle (n = 9) & & & \\
RNA/DNA (\%) & $3.20 \pm 0.34$ & $3.45 \pm 0.28$ & $3.23 \pm 0.47$ \\
Protein/RNA (\%) & $4.74 \pm 0.84$ & $4.67 \pm 0.52$ & $4.99 \pm 0.86$ \\
\hline
\end{tabular}

Values within a row with different letters differ $(\mathrm{p}<0.05)$. Data were represented as means with SD. C: Fish fed with control diet; F: Fish fed with $4 \mathrm{mg} \mathrm{kg}^{-1}$ flavomy cin; S: Fish fed with $100 \mathrm{mg} \mathrm{kg}^{-1}$ silymarin

Table 5: Activity of SOD and level of MDA in serum and liver of Corassius auratus gibelio in different dietary treatment

\begin{tabular}{|c|c|c|c|}
\hline$\underline{\text { Parameters }}$ & $\mathrm{C}$ & $\mathrm{F}$ & $S$ \\
\hline \multicolumn{4}{|l|}{ Serum $(n=9)$} \\
\hline $\mathrm{MDA}\left(\mathrm{nmol} \mathrm{mL} \mathrm{m}^{-1}\right)$ & $15.40 \pm 1.380^{\mathrm{a}}$ & $14.38 \pm 1.300^{\mathrm{a}}$ & $9.29 \pm 1.530^{b}$ \\
\hline $\mathrm{SOD}\left(\mathrm{U} \mathrm{mL}^{-1}\right)$ & $217.20 \pm 6.760^{\mathrm{a}}$ & $191.30 \pm 10.39^{b}$ & $207.90 \pm 4.980^{\mathrm{ab}}$ \\
\hline \multicolumn{4}{|l|}{ Liver $(n=9)$} \\
\hline MDA (nmol $\mathrm{mg}^{-1}$ protein) & $95.74 \pm 15.59^{a}$ & $71.59 \pm 7.170^{\mathrm{ab}}$ & $62.70 \pm 5.530^{b}$ \\
\hline$\underline{\mathrm{SOD}}\left(\mathrm{U} \mathrm{mg}^{-1}\right.$ protein) & $161.70 \pm 19.04$ & $153.60 \pm 19.01$ & $168.90 \pm 20.27$ \\
\hline
\end{tabular}

RNA ( $\mathrm{p}<0.05)$. However, there were no significances in ratio of RNA/DNA and protein/RNA of muscle among three groups $(\mathrm{p}>0.05)$ (Table 4$)$.

Activity of SOD and level of MDA in serum and liver: At the end of experiment, fishes fed with dietary silymarin exhibited a lower $(\mathrm{p}<0.05)$ level of MDA compared to control and flavomycin groups. In comparison with control group, diet supplementation of silymarin decreased $(\mathrm{p}<0.05)$ the level of liver MDA whereas the activity of serum SOD among three groups was not differed (Table 5).

\section{DISCUSSION}

In the present study, diet supplementation of $100 \mathrm{mg} \mathrm{kg}^{-1}$ silymarin or $4 \mathrm{mg} \mathrm{kg}^{-1}$ flavomycin did not affect the growth performance of $C$. auratus gibelio. However, it is tended to increase WGR, crude protein and fat in silymarin group, though not statistically different. Kohno et al. (2002) have also observed the same result of body weight in rats induced by azoxymethane. Soto et al. (2004) had reported that silymarin restored the body weight to normalcy in rats treated with alloxan. Therefore, it is likely that the efficiency of silymarin was correlated with the treatment exerted on animals.

Serum GOT and GPT are the most sensitive markers employed in the diagnosis of hepatic damage as they are cytoplasmic in location and hence released into the circulation after cellular damage (Pradeep et al., 2007). Silymarin supplementation at the dosage of $100 \mathrm{mg} \mathrm{kg}^{-1}$ did not have impact on the liver tissue in term of the similar values of GPT and GOT between control and silymarin groups. It was reported that the rate of protein synthesis in the liver tissue was closely related with the total protein concentrations in the plasma (Banaee et al., 2011). Therefore, the increase of the total protein levels in plasma in silymarin-treated fishes reflected the enhancement of the protein synthesis in liver tissue. This was substantiated by result of higher ratio of protein/RNA in silymarin group. The underlying mechanism is unclear. Similar results have been reported in several experiments of fish fed with diet of plant extracts (Dugenci et al., 2003). In addition, serum total protein is comprised of albumin and globulin which was indicative of drug carrier and immune function, respectively. In the present study, dietary supplementation with silymarin significantly increased the blood globulin level as compared to the flavomycin group, indicating the improvement of immunocompetence in silymarin-treated fishes. The results were in line with the study of Banaee et al. (2011) who have reported increased globulin levels in fishes fed with diet containing $100 \mathrm{mg} \mathrm{kg}^{-1}$ silymarin for 14 days.

Rapidly growing organisms apparently synthesize and accumulate the RNA needed for protein synthesis. Thus RNA and the ratio of RNA to DNA are useful indicatives to growth and synthetic activity of protein (Nakata et al., 1994). In fishes, RNA/DNA ratios were closely related to the trends in growth, both in short-time and long-term (Wilder and Stanley, 1983). In the present study, the ratios of RNA to DNA in liver and muscle tissues were not different under administration of silymarin or flavomycin. This further substantiated the result that silymarin could not affect the growth performance. Furthermore, the white muscle protein, RNA and DNA concentration and the ratio of RNA to DNA were significantly and positively related to Specific Growth Rate (SGR) for wet weight (Carter et al., 1998). Thus, high ratio of muscle protein to RNA may be a indicative parameter of higher growth rate. However, the results suggested that supplementation of silymarin or flavomycin did not affect the ratio of muscle protein to 
RNA, resulting in similar SGR among different groups. Nevertheless, fishes receiving $100 \mathrm{mg} \mathrm{kg}^{-1}$ silymarin had a higher ratio of protein to RNA in liver, indicating that silymarin is benefit for liver protein synthesis.

Silymarin could act as a scavenger of the free radicals and influence enzyme systems associated with glutathione and superoxide dismutase (Valenzuela et al., 1989; Letteron et al., 1990). Fishes receiving $100 \mathrm{mg} \mathrm{kg}^{-1}$ silymarin had a lower level of serum and liver Malondialdehyde (MDA) showing that silymarin may protect tissues or cells from attacking by the free radicals. Generally, the free radical scavenging activity of silymarin can be due to their chemical structure because the number and position of hydroxyl groups in the molecular increases its antioxidant activity (Kiruthiga et al., 2007). However, there were no improvements of the activity of Superoxidation Dismutase (SOD) in liver or blood. This might be due to the lower dosage of silymarin in the diet. The result was in accordance with the studies of Farghali et al. (2000) and Kiruthiga et al. (2007) who have reported that silymarin possessed substantial protective effect and free radical scavenging mechanism against oxidative damage.

\section{CONCLUSION}

This study shows that the dietary supplementation of $100 \mathrm{mg} \mathrm{kg}^{-1}$ silymarin increased the protein synthesis and potentially improved the antioxidative capacity in C. auratus gibelio. The results implicate that silymarin may be used as a feed additive to relieve oxidative stress in aquaculture industry.

\section{ACKNOWLEDGEMENTS}

This research was jointly supported by National Agriculture Science and Technology fund projects of China (Grant No. 2011GB2D100014), Hubei Provincial Research and Development Program (Grant No. 2010BB023) and Natural Science Foundation of Hubei Province (Grant No. 2011CDA051).

\section{REFERENCES}

Banaee, M., A. Sureda, A.R. Mirvaghefi and G.R. Rafei, 2011. Effects of long-term silymarin oral supplementation on the blood biochemical profile of rainbow trout (Oncorhynchus mykiss). Fish Physiol. Biochem., 37: 885-896.

Carter, C.G., C.G. Seeto, A. Smart, S. Clarke and R.J. van Barneveld, 1998. Correlates of growth in farmed juvenile southern bluefin tuna Thunnus maccoyii (Castelnau). Aquaculture, 161: 107-119.
Ceriotti, G., 1955. Determination of nucleic acids in animal tissues. J. Biol. Chem., 21 4: 59-70.

Citarasu, T., 2010. Herbal biomedicines: A new opportunity for aquaculture industry. Aquacult. Int., 18: 403-414.

Citarasu, T., G. Immanuel and M. Marian, 1999. Effects of feeding Artemia enriched with stresstol and cod liver oil on growth and stress resistance in the Indian white shrimp Penaeus indicus post larvae. Asian Fish Sci., 12: 65-75.

Dugenci, S.K., N. Arda and A. Candan, 2003. Some medicinal plants as immunostimulant for fish. J. Ethnopharmacol., 88: 99-106.

Farghali, H., L. Kamenikova, S. Hynie and E. Kmonickova, 2000. Silymarin effects on intracellular calcium and cytotoxicity: A study in perfused rat hepatocytes after oxidative stress injury. Pharmacol. Res., 41: 231-237.

Fleck, A. and D. Begg, 1965. The estimation of ribonucleic acid using ultraviolet absorption measurements. Biochim. Biophys. Acta., 108: 333-339.

Fleck, A. and H.N. Munro, 1962. The precision of ultraviolet absorption measurements in the Schmidt-Thannhauser procedure for nucleic acid estimation. Biochim. Biophys. Acta., 55: 571-583.

Fraschini, F., G. Demartini and D. Espostii, 2002. Pharmacology of silymarin. Clin. Drug Invest., 22: 51-65.

Iwashima, M., J. Mori, X. Ting, T. Matsunaga and $\mathrm{K}$. Hayashi et al., 2005. Antioxidant and antiviral activities of plastoquinones from the brown alga Sargassum micracanthum and a new chromene derivative converted from the plastoquinones. Biol. Pharm. Bull., 28: 374-377.

Kang, J.S., Y.J. Jeon, S.K. Park, K.H. Yang and H.M. Kim, 2004. Protection against lipopolysaccharide-induced sepsis and inhibition of interleukin-1beta and prostaglandin E2 synthesis by silymarin. Biochem. Pharmacol., 67: 175-181.

Kiruthiga, P.V., R.B. Shafreen, S.K. Pandian and K.P. Devi, 2007. Silymarin protection against major reactive oxygen species released by environmental toxins: Exogenous $\mathrm{H} 2 \mathrm{O} 2$ exposure in erythrocytes. Basic Clin. Pharmacol. Toxicol., 100: 414-419.

Kohno, H., T. Tanaka, K. Kawabata, Y. Hirose, S. Sugie, H. Tsuda and H. Mori, 2002. Silymarin, a naturally occurring polyphenolic antioxidant flavonoid, inhibits azoxymethane-induced colon carcinogenesis in male F344 rats. Int. J. Cancer, 101: 461-468.

Kong, X.F., G.Y. Wu, Y.P. Liao, Z.P. Hou and H.J. Liu et al., 2007. Effects of Chinese herbal ultra-fine powder as a dietary additive on growth performance, serum metabolites and intestinal health in early-weaned piglets. Livest. Sci., 108: 272-275. 
Letteron, P., G. Labbe, C. Degott, A. Berson and B. Fromenty et al., 1990. Mechanism for the protective effects of silymarin against carbon tetrachloride-induced lipid peroxidation and hepatotoxicity in mice: Evidence that silymarin acts both as an inhibitor of metabolic activation and as a chain-breaking antioxidant. Biochem. Pharmacol., 39: 2027-2034.

Li, L.L., Y.L. Yin, Y.H. Liu, D.X. Hou, Z.P. Hou, C.B. Yang and X.J. Yang, 2007. Intramuscular administration of zinc metallothionein to preslaughter stressed pigs improves anti-oxidative status and porl quality. Asian-Aust. J. Anim. Sci., 20: 761-767.

Lowry, O.H., N.J. Rosebrough, A.L. Farr and R.J. Randell, 1951. Protein measurement with the Folin phenol reagent. J. Biol. Chem., 193: 265-275.

Muriel, P. and M. Murelle, 1990. Prevention by silymarin of membrane alterations in acute $\mathrm{CCl} 4$ liver damage. J. Applied Toxicol., 10: 275-279.

Muriel, P., T. Garciapina, V. Perez-Alvarez and M. Mourelle, 1992. Silymarin protects against paracetamol-induced lipid peroxidation and liver damage. J. Applied Toxicol., 12: 439-442.

Nakata, K., H. Nakano and H. Kikuchi, 1994. Relationship between egg productivity and RNA-DNA ratio in Paracalanus sp. in the frontal waters of the Kurshio. Mar. Biol., 119: 591-596.

Ohkawa, H., N. Ohishi and K. Yagi, 1979. Assay for lipid peroxides in animal tissues by thiobarbituric acid reaction. Anal. Biochem., 95: 351-358.

Pradeep, K., C.V. Mohan, K. Gobianand and S. Karthikeyan, 2007. Silymarin modulates the oxidant-antioxidant imbalance during diethylnitrosamine induced oxidative stress in rats. Eur. J. Pharmacol., 560: 110-116.

Saller, R., R. Meier and R. Brignoli, 2001. The use of silymarin in the treatment of liver diseases. Drugs, 61: 2035-2063.

Sivaram, V., M.M. Babu, G. Immanuel, S. Murugadass, T. Citarasu and M.P. Marian, 2004. Growth and immune response of juvenile greasy groupers (Epinephelus tauvina) fed with herbal antibacterial active principle supplemented diets against Vibrio harveyi infections. Aquaculture, 237: 9-20.
Soto, C., R. Mena, J. Luna, M. Cerbon and E. Larrieta et al., 2004. Silymarin induces recovery of pancreatic function after alloxan damage in rats. Life Sci., 75: 2167-2180.

Sun, L., T.E. Peterson, M.L. McCormick, L.W. Oberley and J.W. Osborne, 1989. Improved superoxide dismutase assay for clinical use. Clin. Chem., 35: 1265-1266.

Valenzuela, A., M. Aspillaga, S. Vial and R. Guerra, 1989. Selectivity of Silymarin on the increase of the glutathione content in different tissues of the rat. Planta Med., 55: 420-422.

Wilder, I.B. and A.S. Stanley, 1983. RNA-DNA ration as an index to growth in salmonid fishes in the laboratory and in streams contaminated by carbaryl. J. Fish. Biol., 22: 165-172.

Yao, K., Y.L. Yin, W. Chu, Z. Liu and D. Deng et al., 2008. Dietary arginine supplementation increases $\mathrm{mTOR}$ signaling activity in skeletal muscle of neonatal pigs. J. Nutr., 138: 867-872.

Yin, F.G., Y.L. Yin, X.F. Kong, Q.H. He and T.J. Li et al., 2008b. Dietary supplementation with acanthopanax senticosus extract modulates gut microflora in weaned piglets. Aust. J. Anim. Sci., 21: 1330-1338.

Yin, Y.L., H.Y. Zhong, R.L. Huang, C.M. Chen, T.J. Li and Y.F. Pai, 1993. Nutritive value of feedstuffs and diets for pigs. I. Chemical composition, apparent ileal and fecal digestibility. Anim. Feed Sci. Technol., 44: 1-27.

Yin, Y.L., J. McEvoy, W.B. Souffrant, H. Schulze and K.J. McCracken, 2000. Apparent digestibility (ileal and overall) of nutrients and endogenous nitrogen losses in growing pigs fed wheat or wheat by-products without or with xylanase supplementation. Livest. Prod. Sci., 62: 119-132.

Yin, Y.L., Z.R. Tang, Z.H. Sun, Z.Q. Liu and T.J. Li et al., 2008a. Effect of galacto-mannan-oligosaccharides or chitosan supplementation on cytoimmunity and humoral immunity response in early-weaned piglets. Asian-Aust. J. Anim. Sci., 21: 723-731. 